\title{
Penerapan Program Manejemen Terpadu Balita Sakit (MTBS) Deteksi Dini Pneumonia Dengan Tingkat Kepatuhan Petugas Dalam Memberikan Pelayanan Di Puskesmas Bagu
}

\author{
Baiq Fiya Apriani \\ Fiyabaiq@gmail.com
}

Fakultas Kesehatan, Universitas Qamarul Huda Badaruddin

\begin{abstract}
ABSTRAK
Tingkat kesakitan dan kematian adalah salah satu indikator keberhasilan dalam peningkatan derajat kesehatan. Pneumonia banyak menyerang anak-anak, sementara terdapat masalah dalam program kesehatan masyarakat. Sehingga dapat dikatakan bahwa pengobatan pneumania yang dilakukan di Bagu tidak maksimal. Hal ini disebabkan tidak tepatnya pelaksanaan Program MTBS. Penelitian ini dilakukan untuk menganalisa hubungan antara kepatuhan petugas dengan penerapan program MTBS pada deteksi dini pneumonia. Penelitian ini menggunakan metode "croscectional", dengan populasi 20 orang tenaga kesehatan di Puskesmas Bagu, dengan implementasi Program MTBS pada deteksi dini pneumonia sebagai "dependen variable". Data dikumpulkan dengan kuesioner untuk mengetahui pengetahuan dan sikap serta observasi pelaksanaan tindakan pengobatan pasien pneumonia. Lalu dianalisa dengan menggunakan uji statistik metode "sperman rho corelation" dengan hasil $p<0,05$. Hasil ini memperlihatkan adanya hubungan antara kepatuhan petugas dengan penerapan program MTBS pada deteksi dini pneumonia dengan nilai $\mathrm{p}=0,083$ dan $\mathrm{r}=-0,397$. Penelitian ini menyimpulkan bahwa tingkat kepatuhan petugas dengan penerapan program MTBS pada deteksi dini pneumonia baik.
\end{abstract}

Kata kunci: Kepatuhan - program MTBS - deteksi dini pneumonia

\begin{abstract}
Morbidity and mortality rate is one of succes indilator in health improtement. Pneumoni the most children attack. In fact public health programs have trouble. So pneumonie tretment in dompu is not maxime. It coused implementation of MTBS program not corecetly. This research aimed to analyze corelation between knowledge and attitude with MTBS program implementation in pneumony early detection. It used croos sectional study, populations are provider in 20 Bagu public health center. Sample collected with included criteria. Dependen variable is MTBS program implementation in pneumony early detection, moderator variable is equpmentand istitution approach. The data collected with cuasioner for knowledge and attitude observation for proder role to treats penumonie. Then Analyzed with sperman rho corelation statistik test with $p \leq 0,05$ Result showed there was corelation between attitude and responden action in MTBS program implementation with $\mathrm{p}=0,083, \mathrm{r}=-0,397$. It concluded that higher knowledge attitude not exactty will good action. It coused a lot of eksternal factors influenced.
\end{abstract}

Keywords: Knowledge - attitude - MTBS program - pneumony detection child. 


\section{A. LATAR BELAKANG}

Angka kesakitan dan kematian balita merupakan salah satu indikator keberhasilan pembangunan di bidang kesehatan. Pneumonia merupakan salah satu penyakit yang sering dialami oleh balita, setiap tahun anak di dunia meninggal sebelum mencapai umur 5 tahun dan penyebab utamanya karena pneumonia, diare, malaria, campak, malnutrisi dan sering kali merupakan kombinasi dari/keadaan tersebut diatas.

Pelaksanaan Program MTBS di Puskesmas Bagu sudah dilaksanakan sejak tahun 2001 sampai saat ini [1]. Dalam rangka persiapan pelaksanaan Manajemen Terpadu Balita Sakit di setiap puskesmas ditunjuk beberapa tenaga (minimal 3 orang) untuk mengikuti pelatihan di Dinas Kesehatan tentang Manajemen Terpadu Balita Sakit agar pengetahuan mereka bertambah mengenai berbagai jenis penyakit secara tepat dan cepat yang terdiri dari tenaga medis dan tenaga paramedic. Pelatihan sederhana di masing - masing puskesmas dilakukan secara "On The Job Training", yaitu satu petugas terlatih dan sedang dilatih melakukan pemeriksaan pada balita sakit dengan menggunakan Manajemen Terpadu Balita Sakit.

Sarana dalam pelaksanaan Manajemen Terpadu Balita Sakit meliputi formulir Manajemen Terpadu Balita Sakit, Kartu Nasehat Ibu, formulir rujukan, buku register kunjungan Manajemen Terpadu Balita Sakit, ruang pemeriksaan khusus balita, pokja oralit dan pokja gizi. Dalam menentukan pembagian tugas pada pelaksanaan Manajemen Terpadu Balita Sakit, Kepala Puskesmas mengadakan pertemuan dengan seluruh karyawan yang terlibat langsung. Untuk petugas yang telah mengikuti pelatihan di tingkat pusat, diberi tugas mengkoordinasikan petugas - petugas lain yang belum mendapat pelatihan. Direncanakan pula adanya pelatihan secara sederhana supaya petugas terlatih bertambah banyak.

Dalam memulai penerapan Manajemen Terpadu Balita Sakit, tidak ada patokan khusus besarnya prosentase kunjungan balita sakit yang ditangani dengan pendekatan MTBS. Tiap Puskesmas perlu memperkirakan kemampuannya mengenai seberapa besar balita sakit yang akan ditangani pada saat awal penerapan dan kapan akan dicapai cakupan $100 \%$.

Berdasarkan data Dinas Kesehatan Kabupaten Lombok Tengah pada tahun 2010 jumlah balita sebanyak 85.279 balita. Sedangkan berdasarkan data cakupan pelayanan tecatat penyakit ISPA sebanyak didapatkan 46.185 $(54,15 \%)$ kasus, dimana kasus pneumonia sebanyak $6.394(13,84 \%)$ dan non pneumonia sebanyak $39.791(86,15 \%)$, jumlah balita dan kematian balita sebanyak $29(0,03 \%)$ kasus. Sedangkan pada tahun 2011 jumlah balita sebanyak 101.828 balita. Sedangkan berdasarkan data cakupan pelayanan tercatat penyakit ISPA sebanyak $44.312(45,51 \%)$ kasus, dimana kasus pneumonia sebanyak $6.021(5,91 \%)$ dan non pneumonia sebanyak $38.293 \quad(37,60 \%)$, dan kematian balita sebanyak $15(0,01 \%)$ kasus. Pada tahun 2012 jumlah balita sebanyak 101.828 balita dengan kasus ISPA tercatat sebanyak $44.267 \quad(43,27 \%)$ kasus, dimana kasus pneumonia sebanyak $13.865(13,61 \%)$ dan non pneumonia sebanyak $30.402(29,85 \%)$, dan kematian balita sebanyak $19(0,01 \%)$ kasus. [1]

Sedangkan berdasarkan data catatan hasil pelayanan kesehatan di Puskesmas Bagu tahun 2010 jumlah balita sebanyak 2.873 balita. Penyakit ISPA tercatat sebanyak $1.260(43,85 \%)$ kasus, dimana kasus pneumonia sebanyak 289 $(10,05 \%)$ dan kasus non pneumonia sebanyak $971(33,79 \%)$, dan kematian balita sebanyak 9 $(0,31 \%)$ kasus. Pada tahun 2011 jumlah balita sebanyak 3.713 balita. Penyakit ISPA 1.355 
$(36,46 \%)$ kasus, dimana kasus pneumonia sebanyak $202(5,44 \%)$ dan kasus non pneumonia 1153 (31,05\%), kematian balita sebanyak 7 $(0,18 \%)$ kasus. Pada tahun 2012 jumlah balita sebanyak 3.713 balita. Penyakit ISPA 1.401 $(37,73 \%)$ kasus, dimana kasus pneumonia 491 $(13,22 \%)$ dan kasus non pneumonia 911 $(24,53 \%)$, dan kematian balita sebanyak 5 $(0,13 \%)$ kasus.

Manajemen Terpadu Balita Sakit (MTBS) menjelaskan secara rinci cara menerapkan proses pelayanan dalam menangani balita sakit yang datang ke fasilitas rawat jalan. Keterpaduan pelayanan tidak hanya pelayanan kuratif berupa pengobatan penyakit saja, namun sekaligus pelayanan preventif seperti imunisasi, pemberian vitamin A, menilai dan memperbaiki cara pemberian ASI serta pelayanan promotif seperti memberikan konseling kepada ibu cara merawat dan mengobati anak sakit dirumah serta masalah pemberian makanan dan sebagainya. Dalam menangani balita sakit tenaga kesehatan secara aktif dan terstruktur menilai adanya tanda-tanda gejala penyakit dengan cara: tanya, lihat, dengar, raba, membuat klasifikasi, menentukan tindakan dan mengobati anak, memberikan konseling serta memberikan pelayanan tindak lanjut pada saat kunjungan ulang. Meskipun MTBS sudah dilakukan di Puskesmas Bagu namun masih terdapatnya angka yang signifikan pada kasus ISPA, sehingga tertarik untuk dilakukan penelitian.

\section{B. METODE PENELITIAN}

Desain penelitian adalah seluruh dari perencanaan untuk menjawab pertanyaan penelitian dan mengantisipasi beberapa kesulitan yang mungkin timbul selama proses penelitian. Desain yang digunakan dalam penelitian ini adalah metoda "Cross Sectional", yaitu mempelajari hubungan antara variabel bebas yaitu pengetahuan dan sikap dengan variabel tergantung yaitu penerapan program MTBS pada deteksi dini pneumonia. Tentunya tidak semua objek penelitian harus diperiksa pada hari atau saat yang sama, akan tetapi baik variabel bebas maupun variabel tergantung dinilai hanya satu kali saja. Faktor efek tersebut diukur menurut keadaan atau statusnya pada waktu dilakukan observasi [2].

Populasi adalah keseluruhan obyek penelitian atau obyek yang akan diteliti [3]. Populasi dalam penelitian ini adalah semua petugas kesehatan yang telah mendapat pelatihan Manajemen Terpadu Balita Sakit di Puskesmas Bagu. Sedangkan, sampel dalam penelitian ini adalah adalah sebagian dari keseluruhan obyek yang diteliti dan dianggap mewakili seluruh populasi[3]. Pada penelitian ini sample yang digunakan yaitu Total Sampling artinya seluruh tenaga kesehatan yang telah mendapatkan pelatihan Manajemen Terpadu Balita Sakit di Puskesmas Bagu.Pada penelitian ini menggunakan Total Sampling artinya semua petugas dijadikan sampel penelitian. Pada penelitian ini sampel yang di teliti sebanyak 20 orang petugas.

\section{HASIL DAN PEMBAHASAN Karakteristik Demografi Responden}

Data ini menggambarkan karakteristik responden/ petugas kesehatan yang berada di Puskesmas Bagu Kabupaten Lombok Tengah dilihat berdasarkan tingkat umur, pendidikan, status kepegawaian.

1. Distribusi responden berdasarkan umur

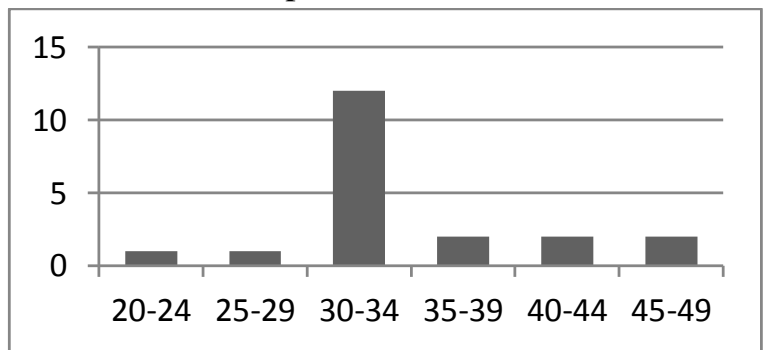

Gambar 4.1

Distribusi Responden berdasarkan Umur di Puskesmas Bagu Kabupaten Lombok Tengah Bulan Juni 2013 
Diagram diatas menunjukkan sebagian besar responden berumur 30-34 tahun sebanyak 11 orang (55\%) dan sebagian kecil berumur 20-24 tahun sebanyak 1 orang $(5 \%)$
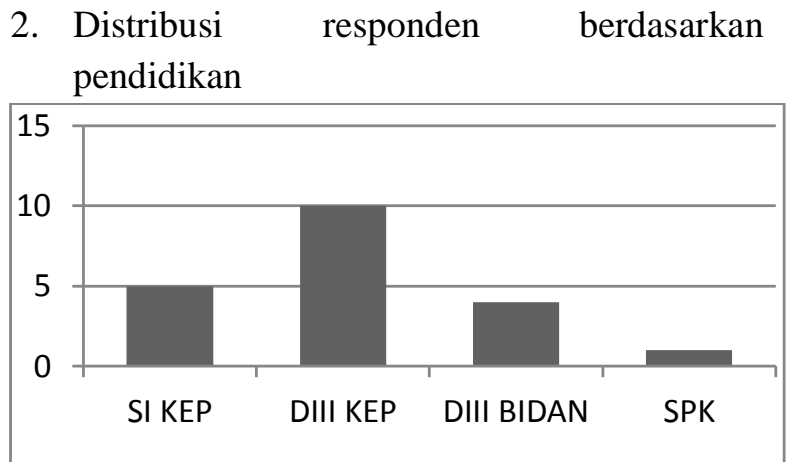

Gambar 4.2 Distribusi Responden Berdasarkan

Pendidikan di Puskesmas Bagu Kabupaten

Lombok Tengah Bulan Juni 2013

Berdasarkan diagram diatas ditunjukkan bahwa sebagian besar responden berpendidikan DIII Keperawatan 9 orang (45\%). Dan sebagian kecil yang berpendidikan SI Keperawatan 5 orang (25\%), DIII Kebidanan 5 orang (25\%) dan SPK 1 orang $(5 \%)$.

3. Distribusi responden berdasarkan status kepegawaian

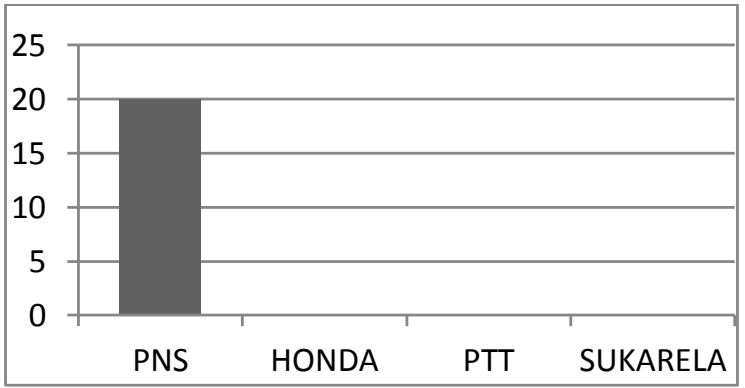

Gambar 4.3

Distribusi Responden Berdasarkan Status

Kepegawaian di Puskesmas Bagu Kabupaten

Lombok Tengah Bulan Juni 2013

Diagram diatas diatas menunjukkan bahwa seluruhnya responden berstatus Pegawai Negeri Sipil (PNS).

\section{Pengetahuan responden}

Pengetahuan responden tentang penerapan program MTBS pada deteksi dini pnemoni adalah baik $(70 \%)$, dan sebagian memiliki pengetahuan cukup (30\%). Pengetahuan responden baik terutama dalam hal mengenal tanda dan gejala pneumonia serta klasifikasi dan penatalaksanaan pneumonia sedangkan pengetahuan cukup khususnya tentang pengertian dan akibat kalau pneumonia tidak ditangani dengan baik.

Hasil penelitian ini didukung dengan tingkat pengetahuan responden dalam penerapan program MTBS pada deteksi dini pnemoni sebagian besar baik dikarenakan responden berpendidikan DIII Keperawatan. Sedangkan pengetahuan baik dalam mengenal tanda dan gejala pneumonia serta klasifikasi dan penatalaksanan pneumonia oleh karena rata-rata masa kerja responden adalah lebih dari 10 tahun. Sehingga responden cenderung menguasai tingkat aplikasi.

\section{Sikap Responden}

Hasil Penelitian menunjukkan ada hubungan antara responden yang memiliki sikap positif (95\%) dan hanya sebagian yang menunjukkan sikap negatif (5\%). Sikap responden positif terutama adalah hal menguasai cara penanganan pneumonia dan melakukan deteksi dini pneumonia.

Sesuai pendapat Azwar A [4] yang menyatakan bahwa salah satu faktor yang mempengaruhi tingkat kepatuhan petugas adalah faktor orang lain yang dianggap penting. Pada umumnya, individu cenderung untuk memiliki sikap yang konformis atau searah dengan sikap orang yang dianggap penting. Kecenderungan ini antara lain dimotivasi oleh keinginan untuk beraktifitas dan keinginan untuk menghindari konflik dengan orang yang dianggap penting. Ilustrasi mengenai pembentukan sikap dapat dilihat pada situasi dimana terdapat hubungan atasan bawahan. Sangatlah umum terjadi bahwa sikap atasan terhadap suatu masalah diterima dan dianut oleh bawahan tanpa landasan afektif maupun kognitif yang relevan dengan obyek 
sikap. Seringkali keserupaan sikap demikian semata-mata didasari oleh kepercayaan yang mendalam kepada atasan. Pernyataan tersebut didukung oleh Allprot (1954) seperti dikutip Notoatmojo [2] bahwa salah satu komponen sikap adalah kepercayaaan atau keyakinan, ide dan konsep terhadap suatu obyek.

Sikap responden yang hampir seluruhnya positif tersebut oleh karena program MTBS merupakan instruksi dari Kepala Dinas Kesehatan Kabupaten Lombok Tengah untuk dijalankan di Puskesmas Bagu. Sikap Responden lebih menguasai dalam cara penanganan dan deteksi dini dikarenakan program MTBS lebih aplikatif dan kurang membahas tentang konsep pneumonia, sehingga untuk pemahaman responden tentang konsep penyakit pneumonia cenderung bersikap negatif.

\section{Penerapan Program MTBS pada deteksi dini Pneumonia}

Hasil penelitian menunjukkan sebagian besar responden menerapkan tindakan yang baik dalam penerapan program MTBS pada deteksi dini pneumonia (75\%) sedangkan yang tindakannya cukup ada (25\%) khususnya dalam mengidentifikasi tanda dan gejala, tindakan responden rata-rata baik, sedangkan cukup dalam hal mengklasifikasi tanda dan gejala serta penatalaksanaan pneumonia.

Teori Lawrence Green seperti di kutip Notoatmojo [2] menyatakan bahwa tersedianya fasilitas dan sarana merupakan enabling factor yang mempengaruhi seseorang dalam berperilaku. Pernyataan tersebut didukung teori Snehandu B.kar seperti dikutip Notoatmojo bahwa seseorang akan berperilaku bila terdapat situasi yang memungkinkan untuk bertindak. Pernyataan diatas sesuai dengan teori WHO seperti dikutip Notoatmojo bahwa alasan pokok seseorang berperilaku adalah adanya pengetahuan, kepercayaaan, sikap, orang penting sebagai referensi, sumber-sumber daya (resources) dan gaya hidup.

Penerapan Program MTBS menunjukkan sebagian besar cukup, salah satu faktor penyebabnya adalah karena pengetahuan responden rata-rata cukup, adanya instruksi dari atasan untuk melaksanakan progaram MTBS, sedangkan pelaksanaan yang kurang maksimal, oleh karena sarana pendukung dalam pelaksananan deteksi dini pneumonia masih ada beberapa sarana yang tidak tersedia, seperti: Timer, bahan tradisional pelega tengorokan (kecap dan jeruk nipis) yang tidak disediakan penyediaan obat injeksi ampicillin untuk kasus pnemoni yang segera dirujuk terbatas. Dan terbatasnya penyediaan format penatalaksanaan MTBS .

\section{Hubungan antara tingkat kepatuhan petugas dengan penerapan Program MTBS pada deteksi dini pneumonia}

Hasil uji statistik dengan menggunakan korelasi Spearman Rho didapatkan tingkat signifikansi $\mathrm{p}=0,000$ dan koefisien korelasi $\mathrm{r}=$ 0,882, yang berarti $\mathrm{H} 0$ ditolak $\mathrm{H} 1$ diterima dan terdapat hubungan yang sangat kuat antara tingkat kepatuhan petugas dengan tindakan responden dalam penerapan program MTBS.

Menurut Lawrence Green, seperti dikutip Notoatmodjo [2] yang menganalisis faktor-faktor yang mempengaruhi manusia dari tingkat kesehatan salah satunya adalah pengetahuan yang merupakan faktor prediposing. Pernyataan tersebut didukung oleh Who seperti dikutip Notoatmodjo [2] bahwa pengetahuan yang diperoleh dari pengalaman sendiri atau pengalaman orang lain menentukan seseorang untuk berperilaku tertentu.

Pengetahuan responden merupakan salah satu faktor yang menyebabkan tindakan responden dalam penerapan program MTBS pada deteksi dini pneumonia. Tindakan yang didasari oleh pengetahuan akan bersifat 
langgeng daripada yang tidak didasari oleh pengetahuan. Sehingga responden dengan pengetahuan baik maka tindakan dalam penerapan MTBS pada deteksi dini pneumonia baik pula, sebaliknya apabila pengetahuan kurang maka tindakan responden akan kurang. Pengetahuan baik responden tidak semuanya diikuti dengan penerapan yang baik, hal ini bisa disebabkan karena usia responden yang sebagian besar adalah dewasa madya sehingga keinginan untuk tahu dan ingin belajar mulai berkurang.

Pada responden ini ada masalah interen dengan keinginan untuk ditempatkan dan dimutasikan di puskesmas lain yang sangat jauh dengan tempat responden berdomisilir dan responden memiliki anak yang masih kecil untuk ditinggal, sehingga mempengaruhi sikap responden dalam melakukan aktifitas pelayanan di puskesmas.

\section{Hubungan antara tingkat kepatuhan petugas dengan penerapan program MTBS pada deteksi dini pneumonia}

Hasil uji Statistik menggunakan korelasi sperman rho ( $\mathrm{r}$ ) terdapat hubungan antara tingkat kepatuhan petugas dengan penerapan program MTBS, dengan signifikasi $\mathrm{p}=0,083$ dan koefisien korelasi $r=-0,397$. Sikap responden sebagian besar positif (95\%) hal ini ditunjukkan pada karakteristik responden berdasarkan sikap. Menurut WHO seperti dikutip Notoatmodjo (2003) bahwa sikap akan terwujud dalam tindakan tergantung pada situasi saat itu, mengacu pada pengalaman orang lain, berdasarkan pada banyak atau sedikitnya pengalaman seseorang, dan nilai dalam masyasrakat. Pernyataan tersebut didukung oleh Warner dan Defluer seperti dikutip Azwar [4] mengemukakan tiga postulat guna mengidentifikasikan tiga pandangan umum mengenai hubungan sikap dan perilaku yaitu : Postulat konsistensi, Postulat variasi independen, dan postulat konsistensi tergantung. Postulat variasi independen mengatakan bahwa tidak ada alasan untuk menyimpulkan bahwa sikap dan perilaku berhubungan secara konsisten, sikap dan perilaku merupakan dua dimensi dalam diri individu yang berdiri sendiri, terpisah dan berbeda. Mengatasi sikap tidak berarti dapat memperediksi perilaku.

\section{KESIMPULAN}

Berdasarkan hasil penelitian dan analisis tentang hubungan tingkat kepatuhan petugas dengan penerapan program MTBS maka dapat ditarik kesimpulan sebagai berikut:

1. Tingkat kepatuhan petugas dalam penerapan program MTBS pada deteksi dini pneumonia di Puskesmas Bagu di peroleh hasil baik dari 20 responden dengan persentasi $(75 \%)$.

2. Tingkat pengetahuan petugas dalam penerapan program MTBS pada deteksi dini pneumonia di Puskesmas Bagu di peroleh hasil baik dari 20 responden dengan persentasi (70\%).

3. Sikap petugas dalam penerapan program MTBS pada deteksi dini pneumonia di Puskesmas Bagu di peroleh hasil positif dari 20 responden dengan persentasi $(95 \%)$.

4. Dengan demikian terdapat hubungan yang sangat kuat antara pengetahuan dengan tindakan responden dalam penerapan program MTBS pada deteksi dini pneumonia dengan nilai $(p=0,000)$. Sikap tidak berhubungan dengan tindakan responden dalam penerapan program MTBS pada deteksi dini pneumonia ( $\mathrm{p}=0,083 \mathrm{r}=$ 0,397), Sikap responden yang positif belum tentu diikuti oleh tindakan yang baik karena banyak faktor eksternal dan internal baik dari petugas itu sendiri maupun sarana dan fasilitas pendukung deteksi dini pneumonia.

\section{DAFTAR PUSTAKA}

[1] Dinas Kesehatan Daerah Kab. Lombok Tengah. (2012). Buku Laporan 
Pengalaman Penerapan MTBS di Puskesmas Bagu

[2] Sudigdo Sastroasmoro, Sofyan Ismail (1995).

Dasar-dasar Metodelogi Penelitian

Klinis. CV. EGC. Jakarta
[3] Notoatmojo, S. (2002). Metodelogi Penelitian Kesehatan. Rineka Cipta. Jakarta

[4] Azwar, S. (2003). Sikap Manusia Teori dan Pengukurannya. Edisi II. Pustaka Pelajar Offset. Jogyakarta 